\section{THE SPANISH LEGISLATIVE FRAMEWORK FOR HIRING IN COUNTRY OF ORIGIN AND INTERNATIONAL COOPERATION WITH THIRD COUNTRIES IN THE CONTEXT OF THE EUROPEAN UNION'S MIGRATION POLICY}

\author{
Asunción Asín-Cabrera \\ Universidad de La Laguna \\ masinca@ull.es
}

\begin{abstract}
Cómo citar este artículo/Citation: Asín-Cabrera, A. (2016). "The Spanish Legislative framework for hiring in country of origin and International Cooperation with Third Countries in the Context of the European Union's Migration Policy". Arbor, 192 (777): a288. doi: http://dx.doi.org/10.3989/ arbor.2016.777n1004
\end{abstract}

Received: September 12th, 2013. Accepted: October 31st, 2014.

ABSTRACT: The influx of immigrants from third countries in search of new opportunities in Spain makes it necessary for these flows to be regulated, in the exercise of state competence and in compliance with, and in respect of, European Union migration policy. Rational management of migration flows inevitably involves revising Spain's foreign relations by strengthening international dialogue and concluding bilateral agreements with third countries. This study aims to analyse one of the main ways to access the Spanish labour market, namely the "collective management of hiring in country of origin", as well as international cooperation between Spain and non-EU countries in the regulation and management of migration flows. Furthermore, Mobility Partnerships, a cooperation mechanism instigated by the European Union, are examined, with particular consideration given to the management of migration flows and labour migration from third countries. Those negotiated with Cape Verde and Morocco are of singular importance to Spain.

KEYWORDS: External dimension of EU migration policies. Collective management of hiring in country of origin. International bilateral agreements. Mobility Partnerships.

\section{EL MARCO LEGISLATIVO ESPAÑOL PARA LA CONTRATACIÓN EN EL PAÍS DE ORIGEN Y LA COOPERACIÓN INTERNACIONAL CON TERCEROS PAIÍSES EN EL CONTEXTO DE LA POLÍTICA MIGRATORIA DE LA UNIÓN EUROPEA}

Copyright: (C) 2016 CSIC. This is an open-access article distributed under the terms of the Creative Commons Attribution-Non Commercial (by-nc) Spain 3.0 License

RESUMEN: La afluencia de inmigrantes procedentes de terceros países en el Estado español en busca de nuevas oportunidades, implica la necesidad de regular estos flujos en el ejercicio de sus competencias estatales y en el cumplimiento y respeto de las competencias de la Unión Europea en materia migratoria. Una gestión racional de los flujos migratorios pasa, inevitablemente, por la revisión de las relaciones exteriores del Estado español mediante el refuerzo del diálogo internacional y la celebración de acuerdos bilaterales con terceros países. El presente estudio tiene como objetivo, el análisis de una de las principales vías de acceso al mercado laboral español, como es "la gestión colectiva de contratación en origen" y de la cooperación internacional desarrollada por el Estado español con países extracomunitarios en el ámbito de la regulación y ordenación de flujos migratorios. Además de ello, se abordan otros mecanismos de cooperación propiciados por la Unión Europea, como son las Asociaciones de movilidad, con gran incidencia en la gestión de los flujos migratorios y en la migración laboral procedentes de terceros países y dentro de las cuales, las negociadas con Cabo Verde y Marruecos, revisten una singular importancia para el Estado español.

PALABRAS CLAVE: Dimensión Exterior de la política migratoria de la U.E. Gestión colectiva de contratación en origen. Acuerdos internacionales bilaterales. Asociaciones de movilidad. 


\section{INTRODUCTION}

In recent years, the impact of migration at EU level has led to the development of a comprehensive common immigration policy within the Union. EU measures have been introduced in accordance with the powers conferred by the Treaties of the Union.

The Treaty of Lisbon, which entered into force on 1 December, 2009, states that the European Union has shared competence in the area of freedom, security and justice (Article 4.2 (j) of the Treaty on the Functioning of the European Union). It is within this framework that the powers of the Union in the area of migration falls, as specified in Chapter 2 of Title $V$ of Part Three of the Treaty on the Functioning of the European Union (TFEU) concerning policies on border checks, asylum and immigration.

Since this is a shared competence, it coexists with that reserved to Member States in the Treaties. The powers of the European Union may not, therefore, extend beyond the limits set by them. Thus, Member States retain national competence in legislation and the adoption of legally binding acts on migration. They may exercise these powers as long as the Union has not previously exercised its powers, or in the case of intervention, insofar as EU legislation allows a degree of discretion. Thus, for example, the competence of the Union does not affect the competence of Member States in the integration of third-country nationals legally residing in the EU. Nor in determining volumes of admission of "third-country nationals coming from third countries" to their territory in order to seek work, whether employed or self-employed. (Article 79.4 and 5 of the TFEU).

Another area of competence of particular importance for this study, in that it explicitly affects the Union's external action, is that provided for in Article 79.3 of the TFEU, which states: "The Union may conclude agreements with third countries for the readmission to their countries of origin or provenance of third-country nationals who do not or who no longer fulfil the conditions for entry, presence or residence in the territory of one of the Member States". This competence is also shared and therefore does not exclude the possibility of bilateral readmission agreements being concluded by Member States.

The EU has been actively working within the purview of this competence towards establishing a common migration policy. An important reflection of this are the initiatives and actions that have been carried out within the framework of the Global Approach to migration issues, whose starting point was the Communication from the Commission on 30 November, 2005. This already contained a number of concrete priority measures to address the challenges of migration, which were the basis for further discussions on Africa and the Mediterranean region in the European Council (Communication from the Commission on priority actions for responding to the challenges of migration: First follow-up to Hampton Court, COM (2005) 621 final, 30 November 2005).

Since then the European Union's Global Approach to migration policy has been the subject of several specific Communications from the Commission. It can be quite clearly deduced from these Communications that the Global Approach is an evolving process. Evidence of this may be found in the Commission's Communication on the Global Approach to Migration and Mobility (GAMM), drawn up in Brussels and dated 18 November, 2011 (COM (2011) 743 final).

The Global Approach is multidimensional and is based on four equally important pillars: 1) organising and facilitating legal migration and mobility; 2) preventing and reducing irregular migration and trafficking in human beings; 3) promoting international protection and enhancing the external dimension of asylum policy; and 4) maximising the development impact of migration and mobility.

Development of these four pillars requires the renewed Global Approach to Migration and Mobility to be embedded in the "EU's overall foreign policy framework", including development cooperation. Within this framework, dialogue and cooperation on migration and mobility between Member States of the European Union and third countries located in different geographical regions is a priority.

Cooperation with third countries is not only aimed at combating illegal immigration, but also at promoting their development. In this sense, "the EU helps third countries to manage migration flows and supports the provision of resources to immigrants and their countries of origin" (COM (2011) 743 final).

Current Spanish immigration policy cannot be devised in isolation from the challenges and goals established in the Global Approach to Migration and Mobility. Without losing sight of European migration policy, this study analyses one of the main access mechanisms, as established by immigration law, to the Spanish labour market: "the collective management of hiring in country of origin". It also takes a look at the way in which Spain exercises its competence in developing 
international cooperation with non-EU countries in the regulation and management of migration flows. Furthermore, Mobility Partnerships, a cooperation mechanism instigated by the European Union, are examined, with particular consideration given to the management of migration flows and labour migration from third countries. Those negotiated with Cape Verde and Morocco are of singular importance to Spain.

\section{LEGAL APPROACH TO THE COLLECTIVE MANAGE- MENT OF HIRING NON-EU FOREIGN WORKERS IN COUNTRY OF ORIGIN}

In Spain, the commitment to a migration model based on the requirements and demands of the domestic labour market may be found in the foundations of policy decisions that eventually become part of immigration law.

Royal Decree 557/2011, of 20 April, approving the regulation of Organic Law 4/2000, on the rights and freedoms of foreigners in Spain and their social integration, after its reform by Organic Law 2/2009 (RD $557 / 2011$ ), is an executive regulation drawn up in the midst of crisis and economic recession in Spain.

This regulation seeks to offer legal and regulatory responses, taking into account the changing migration cycle caused by the economic crisis, which has meant that legal provisions must be adapted to the circumstances. In the context of temporary and circular migration, the type of contract designed for workers who are not in Spain when applying for the job offer are fixed-term contracts related to seasonal activities. This is in addition to the "contingente" (quota), which is now referred to as "collective management of hiring in country of origin" (Ramos Quintana, 2011), to which we now turn.

The reform of Organic Law 4/2000, on the rights and freedoms of foreigners in Spain and their social integration, introduced by Organic Law 2/2009 of 11 December (LOEXIS), brought about a change in terminology, with "foreign workers quota" being replaced with "collective management of hiring in country of origin". However, we can say that, beyond this change of name, the reform has not led to substantial changes in the way that this type of contract functions, nor in the features that define it.

The collective management of hiring in country of origin, provided for by Article 39 of the LOEXIS Act, is a mechanism for accessing jobs that enables the hiring of foreign workers who neither live, nor are residents, in Spain, and who are selected in their countries of origin on the basis of generic job offers presented by employers. It is a system for managing foreign labour that was designed by the host country in keeping with its own needs and interests, and introduced in order to meet the requirements of its own labour market (Fernández Collados, 2011).

The process is managed through a generic assessment of the national employment situation and one of its most important features is its temporary nature, as it is reviewed on a yearly basis. This timeframe is conditioned by the need to guarantee that jobs not covered by the domestic market - i.e. those that nationals, EU and legal residents cannot do - are filled (Barcelón Cobedo, 2012). It is for this reason that respective annual projections are not always established. At the same time, and as laid down by Article 167.1 of RD 557/2011, "after the year for which the figure was established has elapsed, if the numbers hired in country of origin are fewer than originally projected, the Ministry of Labour and Immigration, after consulting the Tripartite Labour Commission for Emigration", may extend the duration of the validity of the remaining number.

The competent authority for establishing the proposed annual projection for job positions is the General Secretariat for Immigration and Emigration (now Ministry of Employment and Social Security). To this end, in accordance with Article 168.1 of RD 557/2011, "information on the national employment situation provided by the Public Employment Service should be taken into account, as should the proposals which, in consultation with the most representative trade union and business organisations in their respective fields, are presented by the Autonomous Communities. They shall make these proposals after they have received applications from business organisations and relevant information from the most representative unions at provincial level."

Once the proposal has been drawn up, and in line with regulatory provisions, it is presented by the General Secretariat for Immigration and Emigration to the Interministerial Commission on Immigration Affairs, which will then advise as to the approval of the annual ministerial order which regulates the collective management of hiring in country of origin.

\section{I.1. Order ESS/1/2012 of 5 January, regulating the collec- tive management of hiring in country of origin for 2012 and Orders extending its validity to 31 December, 2015}

The projection for 2015 of job positions that may be filled by the collective management of hiring in country of origin, to which only non-EU workers 
who are not residents in Spain will have access, was published by Order ESS/1/2012 of 5 January (BOE [Official State Gazette], 6 January, 2012), Order EES/285/2012 of 27 December, which extended its validity to 31 December, 2013 (BOE, 1 January, 2013), Order ESS/2445/2013 of 23 December, extending its validity to 31 December, 2014 (BOE, 30 December, 2013) and Order ESS/2505/2014 of 29 December, extending its validity to 31 December, 2015 (BOE, 1 January 2015).

As stated in the single article of Order ESS/2505/2014, the extension of the term of Order ESS/1/2012 is "solely for the purpose of hiring workers for seasonal agricultural work." It is therefore a much more restrictive Order than that of 5 January, 2012, which also included building or service jobs, the duration of which could not exceed one year, in the construction of industrial or power plants, of infrastructure, buildings and railway networks, of gas supply systems, electricity and telephone grids, in the maintenance of manufacturing equipment and facilities, and their installation and repair.

In line with the provisions of Order ESS/1/2012, job offers for temporary or seasonal agricultural work are formulated generically. However, individual offers may also be submitted on the terms provided for in Articles 14-17 of the aforementioned Ministerial Order.

An important aspect of this regulation, in accordance with the provisions of Articles 39.3 of LOEXIS and 169.5 of RD 557/2011, is the preference for labour originating in countries with which Spain has signed agreements on the regulation and management of migration flows (Article 8 of Order ESS/1/2012) and to which we will refer later. In any case, we should note that this is a preferential, not mandatory, option. It should not therefore be understood to exclude the collective management of hiring of nationals of other countries of origin, some of which have a great tradition of migration toward Spain.

Temporary job offers "exclusively" concern the hiring of workers for seasonal agricultural work. In accordance with the provisions of Article 1.2 of the 2012 Order, this means jobs with a maximum duration of nine months within a period of 12 consecutive months, although they may be managed singly or jointly. In the event of interrelated agricultural works, various temporary job offers may be processed through a single application (Article 11 of Order ESS/1/2012).
I.2. Initial temporary residence and work permit procedures in the framework of collective management of hiring in country of origin

Those authorised to manage job offer applications are the employers, and it also falls to them to submit the corresponding applications themselves or through the relevant employers' organisations.

The procedure for granting initial temporary residence and work permits follows general, established channels, with the procedural specificities incorporated in Article 39.2 of LOEXIS and, most notably, in Articles 170 et seq. of RD 557/2011. It is a collective processing system based on the simultaneous management of a multiple authorisations, submitted by one or more employers for workers selected in their countries of origin, involving, where appropriate, the competent authorities. The process is managed in coordination with the Autonomous Communities that are competent to issue the initial work permit, requiring, in all cases, close collaboration between central government and other public entities and social organisations.

The procedure for hiring workers, as laid down in the Royal Decree 557/2011 and in the Ministerial Order in question, is a system similar to that applicable to all other paid employment in terms of the principal obligations of the employer and of the foreign worker. However, there are certain specific differences in areas such as the selection process, the possibility of taking part in training courses, or the fact that the selection body applies for the permit (Espinosa Calabuig, 2011).

A characteristic element of the final phase in the process of collective management of hiring in country of origin, and one that should be highlighted, is the mandatory and immediate return to their countries of workers holding a residence and work permit upon termination of their employment. Compliance with this commitment of the worker to return to their country of origin is a measure characteristic of temporary and circular migration and of the control of migration flows, whose purpose is simply to prevent situations of irregularity from occurring in our country.

\section{INTERNATIONAL COOPERATION ON MIGRATION IS- SUES: THE CONCLUSION OF INTERNATIONAL BILATERAL AGREEMENTS}

The influx of immigrants from third countries in search of new opportunities in Spain makes it necessary for these flows to be regulated, in the exercise of state competence and in compliance with, and in 
respect of, European Union migration policy. Rational management of migration flows inevitably involves revising Spain's foreign relations by strengthening international dialogue and concluding bilateral agreements with third countries.

Currently, we can identify three different types of international bilateral agreements on migration signed by the Spanish Government: 1) agreements on regulation and management of migration flows; 2) agreements on the readmission of irregular migrants; and 3) framework cooperation agreements on migration.

In this study, we will focus on the main features of the first and third type of international agreements concluded by Spain with third countries and we will take a close look at the legal provisions that affect the management of processes involved in hiring non-EU foreign workers in their countries of origin.

\section{II.1. Bilateral agreements on the regulation and man- agement of migration flows}

The first bilateral agreements regulating international migration concluded by Spain dated from the late eighteenth and early nineteenth centuries. These were the Peace and Friendship Treaties, which laid down provisions that accord certain labour rights, such as the undertaking of work and professional activities, to nationals of the signatory states. Common to these treaties is the "most-favoured-nation clause". This, for example, is the case of the Peace and Friendship Treaties concluded between Spain and Chile (1844), Mexico (1848), Argentina (1853), Uruguay (1870) and Peru (1879).

However, from 2000 onwards there has been a major increase in bilateral agreements on the regulation and management of labour flows. This was a year characterised, as noted by Cachón, by the onset of a "new phase in the constitution of immigrant Spain" and in which the legal channels were overwhelmed by the arrival of immigrants answering the call from the Spanish labour market (Cachón, 2004).

As part of its migration policy, in 2001 Spain adopted the Global Regulation and Coordination Programme for Foreigners and Immigration (GRECO Programme). This programme stipulated, amongst other policy areas, planning measures, through bilateral agreements, for the arrival of immigrants from their home countries. The programme laid down five measures in relation to to this area: a) approval of criteria for the admission of immigrants, especially regarding the determination of annual quotas; b) calculation of worker numbers needed to fill seasonal or permanent jobs; c) identification of countries where the negotiation of immigration agreements is advised, and signature of said agreements; d) regulation, in the agreements, of all aspects relating to the management of migration flows, by virtue of the commitments made by Spain and the signatory country; and e) the introduction of mechanisms for the selection and, where appropriate, training of foreign workers in their countries of origin, for which the contribution of social partners and non-governmental organisations is desirable.

On the basis of the GRECO Programme, the number of bilateral agreements signed by the Spanish government on the regulation and management of labour flows to date amount to nine in total, of which six have been signed with non-EU countries (Colombia, Ecuador, the Dominican Republic, Morocco, Mauritania and Ukraine) and three with Member States of the European Union (Romania, Poland and Bulgaria), these last three with little practical application, today. In addition to these bilateral agreements, we should note other actions entered into with third countries, through different instruments, of no less practical significance, such as Declarations of Intent and Joint Documents. Mention should be made of, amongst others, the Declaration of Intent signed with the Philippines in 2006 on cooperation in the management of migration flows, as well as the Joint Document signed with the same country for the recruitment of health workers, or the Pilot Project for hiring in country of origin with El Salvador in 2007 (Ferrero Turrión and López Sala, 2009).

The importance of these agreements in the management and promotion of the temporary and circular mobility of foreign workers is established in Spanish immigration law, which states that "the job offers made through the collective management of hiring in country of origin are targeted preferentially at countries with which Spain has signed agreements regulating migration flows" (Articles 39.4 LOEXIS and 169.5 RD 557/2011). However, and according to Fernández Collados, we can affirm that at present these agreements - that were originally devised as access routes to the Spanish labour market for foreigners from certain countries - have been "completely denatured and relegated to being subsumed by the system of collective management of hiring in country of origin" (Fernandez Collados, 2011).

Viewed from the personal perspective, the agreements are based on a narrow concept of what is meant by "migrant worker". In this regard, Article 2 
of the agreements signed with Colombia, Ecuador and Morocco define migrant workers as those citizens of the respective state "authorised to engage in paid employment in the territory of Spain." Conversely, the agreements concluded with the Dominican Republic, Mauritania and Ukraine employ broader descriptions than above, describing, for application purposes, "migrant workers" as workers who are nationals of a signatory country, are authorised to take up jobs in the territory of the other signatory country, and are in one of the following categories: a) long-term employees, for an initial period of at least one year, in numbers that are fixed according to available job positions; b) seasonal workers, for a period not exceeding nine months a year, in numbers that are fixed according to available job positions; c) trainees, to improve their professional and linguistic qualifications, for a period of twelve months, extendable by a period of up to six months. This last instance requires a hiring procedure as provided for by the labour laws of the host country in relation to education and training. Moreover, the texts of bilateral instruments concluded with Ukraine and Mauritania establish that these workers must be aged between 18 and 35 .

Five key issues are addressed in the agreements: 1) communication, and form, of job offers; 2) assessment of professional requirements, travel and reception of migrant workers; 3 ) working conditions and social rights of migrant workers; 4 ) special provisions for seasonal workers; 5) provisions relating to the return and readmission of migrant workers. All these issues are accompanied by provisions relating to the involvement, coordination and cooperation of authorities in their implementation and execution.

Without going into a detailed analysis of the agreements, we should point out some aspects relevant to their application.

\section{1) The communication, and form, of job offers}

Once the annual projection of job positions and the expected numbers of jobs that can be filled by the collective management of hiring in country of origin have been approved by the corresponding Ministerial Order, the "generic job offers are preferentially targeted at countries with which Spain has signed agreements on the regulation and management of flows". In this regard, as is explicitly stated in Article 8 of the Ministerial Order regulating the collective management of hiring in country of origin for 2012, "in order to facilitate the availability of workers who fit the occupational profiles required by the labour market, the Department of Migration will exchange information and cooperate with the competent authorities of the countries with which there are agreements on the regulation of migration flows and, in the framework of cooperation established in these agreements, will promote the creation of jobseeker databases in the countries of origin that simplify the task and improve the quality of the selection process".

In accordance with the provisions of the agreements, the communication of job offers is carried out by the Spanish authorities through their embassies in the respective countries. The authorities of those states shall inform the Spanish authorities in turn on the availability of their citizens in response to the job offers open to them. With the exception of the Spanish-Moroccan Agreement, Article 3.3 of these agreements stipulates that upon receipt of direct offers from Spanish employers, the authorities of the country of origin shall inform the Spanish authorities of said job offers.

This measure has been advocated by a sector of Spanish academia as one that seems, in theory at least, an appropriate way of preventing illegal trafficking in workers.

\section{2) Assessment of professional requirements, travel and reception of migrant workers}

The pre-selection, selection, training actions where appropriate - and the hiring of workers require close collaboration and cooperation between the competent national authorities. To ensure transparency in the selection of candidates, provisions are made for mixed selection committees, composed of representatives of the competent authorities of both signatory countries.

The selected employees sign an employment contract in their country of origin, according to the model established by the Spanish authorities, and are then provided with the necessary visa, which is processed urgently by the competent Spanish Consular Office.

\section{3) Working conditions and social rights of migrant workers}

Among other conditions and rights for workers it should be emphatically noted that all the agreements stipulate that workers will be subject to Spanish Social Security legislation and will be entitled to Social Security benefits, unless otherwise provided for in agreements to which the signatory countries are party. 


\section{4) Special provisions for seasonal workers}

In all the international instruments a chapter is dedicated to laying down "special" provisions for seasonal workers.

The conceptual definition of this category of worker acquires different nuances in the various agreements. For instance, the definition contained in the agreement with Morocco is expressed in terms that allow workers to be included in both seasonal work and work related to specific periods. In contrast, in the case of agreements with Latin American countries, the definition of seasonal worker makes reference to season-specific work (Trinidad García, 2005).

\section{5) Provisions relating to the return and readmission of migrant workers}

In all the agreements there are also a number of measures to regulate and facilitate voluntary return (reintegration of migrant workers in their countries of origin at the end of the migration cycle through support programmes for workers), representing added value to the economic and social development of the immigrants' countries of origin. The exception is the labour agreement signed with Morocco in July 2001, which does not include this possibility.

Alongside voluntary return, provisions are also made in relation to mandatory readmission for all those who no longer fulfil the conditions for entry or stay, provided it may be proven that the person concerned is a national of the respective signatory country.

Finally, following the regulatory criteria in force on the date of the signing of the agreements, which are still valid today, they all make reference to the requirement whereby a pledge to return to their countries of origin must be signed. In order for this to be verified, the worker must present himself or herself at the diplomatic mission or consular office which issued the visa within one month of the end of his authorised period of residence in Spain. This pledge is particularly important, since failure to comply with the obligation to return may be considered grounds for denial of subsequent job applications.

\section{II.2. Cooperation Agreements on immigration with African countries}

International cooperation through bilateral agreements with West African countries on migration cooperation and readmission has occupied a central place in Spanish foreign and immigration policy, as well as in the European Union's external action in relation to third countries.

In order to provide an adequate response to the management of migration flows from the African continent and, in particular, sub-Saharan countries, which reached their peak in 2006 with the "cayuco crisis", the Spanish government redirected its foreign and $\mathrm{mi}$ gration policy towards certain West African countries which represented a specific priority for Spain.

This shift in Spanish foreign policy is clearly formulated, for the first time, in the first Action Plan for SubSaharan Africa, approved by the Spanish Government in 2006, which came to mark a before and after in Spanish immigration policy towards African countries (Asín Cabrera, 2008b).

In keeping with the guidelines of the Global Approach to migration, established by the EU in 2005, and recognising that the fight against illegal immigration must be accompanied by a drive to hire workers legally through the provision of recruitment mechanisms in countries of origin, the application of active integration policies, and the promotion of development cooperation measures, Spain formally concluded bilateral framework cooperation agreements on immigration with six African countries: the Republic of Gambia, the Republic of Guinea-Conakry, the Republic of Cape Verde, the Republic of Mali, the Republic of Niger and the Republic of Guinea Bissau.

Unlike the agreements signed by Spain on the regulation and management of labour flows and, most notably, the agreements on the readmission of persons in an irregular situation (Asín Cabrera, 2008a), the framework cooperation or "new generation" agreements are based on the assumption that migration management is a responsibility that must be shared between the migrants' countries of origin, transit and destination. Nor do they lose sight of the positive relationships and synergies that exist between migration and development policies. Accordingly, readmission is no longer "an isolated tool for managing migration flows" (Fajardo del Castillo, 2007), though it certainly does not exclude this.

In order to address the phenomenon of immigration in a comprehensive and balanced way, bilateral instruments comprise a comprehensive set of development measures that are divided into six major lines of action: 1) admission of workers; 2 ) voluntary return of persons; 3 ) integration of residents; 4) migration and development; 5) cooperation in the fight against irregular immigration and trafficking in human beings; and 6) readmission of persons. 
Temporary migration schemes, promoted through the admission of seasonal or temporary workers and through quota systems, are mechanisms for strengthening international cooperation and the fight against the employment of irregular immigrants. In this regard, the framework cooperation agreements aim to promote orderly regulation of labour flows from these third countries, fostering circular migration by hiring nationals of the corresponding African countries in their countries of origin. They may not be currently residing in Spain, as part of the annual quota of foreign workers, and recruitment must be done after an "analysis of labour markets."

As noted by experts, these are agreements that rely on "strict analysis of the labour market" to ensure that foreign workers are not just cheap labour replacing the local workforce. To this end, it is essential that the selected workers have the right skills for the jobs offered, through the introduction of subsidies for training actions targeting workers in their countries of origin (Ferrero Turrión and López Sala, 2009).

Included amongst their objectives and lines of action, the agreements also provide measures that encourage "voluntary return", aimed at avoiding the drain on capital in the issuing countries, limiting the brain drain and promoting the retention of human capital. This is a question directly related to circular migration and "round-trip" mobility, an issue of major strategic importance not only for Spain but also for the European Union. It requires further simplification of the procedures for the admission of both skilled and less skilled workers. In other words, EU and Spanish legislation offers flexible short-term permits, combined with return procedures and guarantees for further employment in subsequent years. Moreover, and very significantly, provision is made for the issuance of short stay or multiple stay visas for nationals who need to travel frequently or for certain categories of person. This requires improved organisation of state consular services in countries of origin and reinforcement of consular Instructions for the issuance of these types of visa. In this regard, framework cooperation agreements are drawn up in light of the importance of issuing certain categories of visa for introducing the proposed hiring system. They read as follows: "Each signatory country will continue in its efforts to facilitate, under current legislation, the issuance of multiple stay visas to nationals of the other signatory country in those cases in which the visa applicant is a manager or businessman, researcher or scientist, university professor, re- nowned artist or intellectual, high-level professional athlete, who actively participates in economic, social, scientific, academic, cultural and sporting relations, inter alia, between the two countries."

In addition to the bilateral agreements concluded with the aforementioned African countries, the case of Senegal merits particular attention.

Apart from a Framework Cooperation Agreement between the Kingdom of Spain and the Republic of Senegal, concluded in Dakar on 10 October, 2006, and a cooperation agreement on the prevention of the emigration of unaccompanied minors, signed on 5 December, 2006, Spain has not concluded any specific formal "new generation" immigration cooperation agreement with Senegal. However, the relationships that have been developed between these two States have been very intense and active. The mechanisms that have been used to boost bilateral cooperation on migration are Memoranda of Understanding and Declarations of Intent, two less formal and solemn instruments than international agreements or treaties but with significant practical scope and application.

The first memoranda date from 2006, the first of these being the Memorandum of Understanding of 24 August, 2006, the objective of which was to curb irregular migration bound for the Canary Islands. The texts of these documents did not specify any mechanism for hiring in the country of origin or recruitment figures, and it was not until 15 February, 2007 that a Declaration of Intent was signed between the Spanish Minister of Labour and Social Affairs and the Senegalese Minister of Youth and Employment on cooperation in training, selection and recruitment of Senegalese workers by Spanish employers. This Declaration laid the groundwork for the negotiation of an important Memorandum of Understanding signed on 9 November, 2007, in which hiring quotas for Senegalese migrants in their country of origin were established for the first time (2000 Senegalese workers for the fisheries sector for a duration of two years, and 700 temporary Senegalese workers in the agricultural sector, in particular, picking strawberries). Moreover, "with the desire to promote the development of bilateral relations in labour and social affairs, with the particular aim of establishing migration flows and making hiring in countries of origin possible" for Spanish companies, the Spanish government created the Department of Labour and Social Affairs in the Permanent Diplomatic Mission of Spain in the Republic of Senegal, by Royal Decree 1542/2006, of 15 December (Serón et al., 2011). 


\section{MOBILITY PARTNERSHIPS BETWEEN THE EURO- PEAN UNION, CAPE VERDE, MOROCCO AND TUNISIA}

Alongside the actions of international treaty law, no less important are other international and soft law multilateral mechanisms, favoured by the European Union in bringing about a more efficient management of migration flows from third countries. Other instruments of cooperation include "Mobility Partnerships". These are a key tool of current EU foreign policy on migration and mobility, in which third countries in the Southern and Eastern neighbourhoods - those included in the European Neighbourhood Policy - are a priority (Asín Cabrera, 2015).

Mobility Partnerships between the European Union and third countries, initially called "mobility packages", are a novel and sophisticated instrument of international cooperation in the management of migration flows. They were proposed by the European Commission in 2006 in its Communication to the Council and the European Parliament on "The Global Approach to Migration one year on: Towards a comprehensive European migration policy" and, especially, in the 2007 Communication to the European Parliament, the Council, the European Economic and Social Committee and the Committee of the Regions on "circular migration and mobility partnerships between the European Union and third countries" (COM (2007) 248 final, Brussels, 16.5.2007). These instruments are part of the general framework of external relations with third countries and are based on the principle of shared responsibility and commitment. They take into consideration geographical balance and respect for the division of powers between the European Union and its Member States. Their content covers a set of "à la carte commitments" that are consistent with the interests of the European Union and the Member States that decide to voluntarily participate in the Partnership, and with the specific situations and needs of the third country in question.

Seven different third countries to date have negotiated a "mobility partnership" and they can be classified, according to their geographical location, in three different groups. The first group comprises the Republic of Moldova (2008), Georgia (2009), Armenia (2011) and Azerbaijan (2013), all eastern neighbours of the EU; the second, Cape Verde (2008), a West African country of origin and transit of migrants to the European Union, and signatory country of the Partnership Agreement between the African, Caribbean and Pacific Group of States, signed in Cotonou on 23 June 2000; and the third group is represented by Morocco
(2013) and Tunisia (2014), southern neighbours in the Mediterranean region.

The starting point of the Mobility Partnerships is the special relationship that each of the third countries maintain with the European Union and bilateral actions on migration that are currently in place between the third country and some Member States. This means that the number of States and the participating Member States differ from one Mobility Partnership to another, since their interests vary considerably depending on the country concerned. However, the partnerships are designed to be "open instruments", a framework for political dialogue and cooperation. This means that Member States not involved $a b$ initio can participate in the near future, after signing the Memorandum of Understanding that formalises the creation of the Partnership.

To date, Spain has participated in the Mobility Partnerships negotiated with Cape Verde, Morocco and Tunisia. Three African countries of priority interest for Spain and with two of which (Cape Verde and Morocco) the Spanish government signed bilateral agreements on labour migration flows and the readmission of immigrants. Along with Spain, the countries also participating in the Mobility Partnership with Cape Verde are France, Luxembourg and Portugal; in that in place with Morocco, these are Belgium, Germany, France, Italy, Netherlands, Portugal, Sweden and United Kingdom, all Member States of the European Union, all receiving significant numbers of Moroccan migrants. Finally, the countries participating in the Mobility Partnership with Tunisia, along with Spain, are Belgium, Denmark, Germany, France, Italy, Poland, Portugal, Sweden and United Kingdom.

The driving force behind Mobility Partnerships in the European Union has been the argument that they offer innovative strategies for a more global, balanced and comprehensive approach to migration and mobility. They have been achieved not only through the inclusion of the various Joint Declarations and annexes, and of a range of security measures of which the return and readmission of non-EU nationals in an irregular situation is an essential aspect, but also through initiatives that open up legal channels for selective and temporary mobility of workers from third countries. Of these initiatives, particular mention should be made of, among others, the actions related to labour migration in order to provide better access to the labour markets of the Member States, the promotion of measures to encourage bilateral agreements on issues related to social security, and the promotion 
of the voluntary return and reintegration of migrants, particularly highly skilled migrants to address the risk of brain drain.

The official line of the European Union has been to argue that the Mobility Partnerships are an example of the change in the external dimension of EU migration policy in recent years. This has meant a shift from an approach focused primarily on security, and aimed at reducing the pressure of migration, to a more transparent and balanced approach that is based on a better understanding of all aspects of immigration and the improvement of accompanying measures for "wellmanaged migration and mobility in a secure environment". However, labour policy promoted by these soft law instruments is essentially guided by the primacy of the security approach, made manifest by the commitment of third countries to cooperate actively with the European Union in the management of migration flows by introducing measures to combat irregular migration, such as the negotiation of readmission agreements.

This is a matter of principle which forms the cornerstone of the Mobility Partnerships; it has been strongly criticised for divesting economic and social development policies of their incentive, since only third countries willing to make this commitment may choose to negotiate a Mobility Partnership.

A clear manifestation of the primacy of this approach may be found in the connection between EU bilateral agreements facilitating short-stay visas, promoted in the framework of Mobility Partnerships, and the simultaneous negotiation of readmission agreements with the EU. A connection that, as stressed by the European Commission in the renewed Global Approach to Migration and Mobility, is of singular importance, as it provides opportunities for labour mobility and, at the same time, bolsters security and reduces the risk of irregular migration flows.

Based on these parameters, the European Union has, together with two agreements with Cape Verde and Armenia in 2012 - on short stay visa facilitation - recently signed two readmission agreements with these countries, dated 19 April, 2013 and similar agreements are expected to be reached with Morocco in the future.

\section{CONCLUDING REMARKS}

1. Policies for managing migration flows and temporary and circular migration in Spain are part of the overall strategic framework of migration and mobility currently being developed by the European Union.
The Spanish labour migration regime is a cross-sectoral policy that involves different types of policies, such as foreign policy or labour market policy and different types of actors. But, the crisis into which Spain has fallen has relegated labour migration governance to a secondary position (Finotelli, 2012).

2. One of the foundations of the management and organisation of migration flows and, in particular, circular and temporary mobility, is hiring in country of origin; one of its main methods is collective management of hiring in country of origin. This is a system that relies on "strict analysis of the needs of the labour market in Spain" and that, at the present time of economic crisis, has led to a substantial decline in the recruitment of workers from third countries in their country of origin.

The recruitment mechanism (contingente) has proven to be more satisfactory with temporary workers in the agricultural sector. But, in general this system has failed because it has been "too dependent on the evolution of the labour market and on the contingent need for the labour force in specific sectors".

3. Rational management of migration flows inevitably involves revising Spain's foreign relations by strengthening international dialogue and concluding bilateral agreements with third countries. In this context, bilateral agreements on the regulation and management of migration flows and framework cooperation agreements on migration with African countries have played an essential role in the management of legal labour migration flows and in the fight against irregular migration: two aspects of the same phenomenon, closely linked to each other, and which, in the words of the European Commission, help to ensure that "the conditions necessary for well-managed migration and mobility in a secure environment" are in place. However, the Spanish government's bilateral contacts with African countries have fallen after 2008. The commitment in Spain to a migration model based on the requirements and demands of the domestic labour market, the emergence and spread of the economic crisis, and growing unemployment levels have led to a very limited applicability in their provisions, many of which have been subsumed by the system of collective management of hiring in country of origin.

4. The process of integration into the European Union and, in particular, the current development of the EU's Global Approach to Migration and Mobility, have shown the need to identify new regulatory options that show greater flexibility and the capacity to 
adapt to changes in migration flows. One option is the "Mobility Partnerships", non-legally binding instruments that are embedded in the external dimension of EU migration policy. These international instruments, though they may be considered a suitable framework for enhancing dialogue and cooperation with third countries - "neighbours" - reflect an inequality in the positions of the parties involved. This is due mainly to the strategy that they employ to implement a policy of temporary and selective job mobility, and the fact that their implementation depends on the commitment made by the third country to "make significant efforts to combat irregular illegal migration" and the obligation to enter into agreements for the readmission of those immigrants who are in an irregular situation.
This attempt to link the Mobility Partnerships with cooperation on readmission is an outcome of the strong prevalence of the security frame and produces a pronounced imbalance between actions on legal labour migration and actions addressing the flows of irregular immigrants (Reslow, 2012) and also in the coordination and implementation of the mobility partnerships.

\section{ACKNOWLEDGEMENTS}

Research developed in the framework of CIRCULAR project (grant number CSO2011-27115) funded by the Spanish National Research Program.

\section{REFERENCES}

Asín Cabrera, M. A. (2008a). Los acuerdos bilaterales suscritos por España en materia migratoria con países del continente africano: especial consideración de la readmisión de inmigrantes en situación irregular. Revista de Derecho Constitucional Europeo, 10, pp. 165-188.

Asín Cabrera, M. A. (2008b). Tratados internacionales recientes en materia de inmigración concluidos con países de África Occidental. En Aja, E., Arango, J y Oliver, J. (dirs.). La inmigración en la encrucijada. Anuario de la Inmigración en España 2007. Barcelona: Edicions Bellaterra, pp. 82-96.

Asín Cabrera, M. A. (2015). Las asociaciones para la movilidad con Cabo Verde, Marruecos y Túnez: un instrumento marco de diálogo, cooperación y coordinación entre la UE y Terceros países. En Donaire Villa, F. J. y Olesti Rayo, A. (coords.). Técnicas y ámbitos de coordinación en el Espacio de Libertad, Seguridad y Justicia. Madrid: Marcial Pons, pp. 163-179.

Barcelón Cobedo, S. (2012). Autorización de residencia por motivos laborales. Régimen general. En Boza Martínez, D., Donaire Villa, F. J. y Moya Malapeira, D. (coords.). La nueva regulación de la inmigración y la extranjería en España. Régimen Jurídico tras la LO2/2009, el Real Decreto 557/2011 y la Ley 12/2009. Valencia: Tirant lo Blanch, pp. 364-419.

Cachón, L. (2004). Los acuerdos bilaterales celebrados por España con Ecuador y Colombia. En Geronimi, E., Cachón, L. y Texidó, E. Acuerdos bilaterales de mi- gración de mano de obra: Estudio de casos. Ginebra: Oficina Internacional del Trabajo, pp. 23-93.

Communication from the Commission to the Council and the European Parliament. Priority actions for responding to the challenges of migration: First follow-up to Hampton Court. Brussels, 30.11.2005. COM (2005) 621 final [on line] [Available from http://eur-lex.europa.eu/legal-content/EN/TXT/PDF/?ur $\mathrm{i}=$ CELEX:52005DC0621\&from=en]

Communication from the Commission to the European Parliament, the Council, the European Economic and Social Committee and the Committee of the Regions. The Global Approach to Migration and Mobility. Brussels, 18.11.2011. COM (2011) 743 final [on line] [Available from http://ec.europa.eu/dgs/ home-affairs/what-we-do/policies/ pdf/1_en_act_part1_v9_com2011743_en.pdf].

Espinosa Calabuig, R. (2011). El trabajador extranjero en España. En Fernández Masiá, E. (dir.) Nacionalidad y Extranjería. Valencia: Tirant lo Blanch, pp. 213-238.

Fajardo del Castillo, T. (2007). Los acuerdos de readmisión de los inmigrantes en situación irregular celebradas en España. En Aldecoa Luzárraga, R. y J.M. Sobrino Heredia, J. M. (coords.) Migraciones y Desarrollo. II Jornadas Iberoamericanas de Estudios Internacionales. Madrid: Marcial Pons, pp. 87-102.

Fernández Collados, M. B. (2011). Artículo 39. Gestión Colectiva de contrataciones en origen. En Cavas Martínez, F. (dir.). Comentarios a la Ley de Extranjería y su nuevo Reglamento. Madrid: Civitas, pp. 695-713.

Ferrero Turrión, R. y López-Sala, A. (2009). Nuevas dinámicas de gestión de las migraciones en España: el caso de los acuerdos bilaterales de trabajadores con los países de origen. Revista del Ministerio de Trabajo e Inmigración, 80, pp. 119-132.

Finotelli, C. (2012). Labour migration governance in contemporary Europe. The case of Spain. Fieri Working Papers. [on line]. [Available from http://www.labmiggov. eu/wp-content/uploads/2012/04/LABMIGOV_WP1_SPAIN_Final-report.pdf].

Ramos Quintana, M. (2011). Acceso al mercado de trabajo y condiciones de trabajo de los inmigrantes en el contexto de la crisis económica. Revista de Derecho Migratorio y Extranjería, 28, pp. 29-68.

Red Europea de Migraciones (EMN) (2010). Migración Temporal y Circular: Evidencia empírica, políticas actuales y opciones futuras en España [on line] [Available from http://extranjeros.empleo. gob.es/es/redeuropeamigracion/Estudios_monograficos/EMN-ES-MigracionCircular.pdf].

Reslow, N. (2012). European policy debate: the Mobility Partnerships. Migration Policy Brief $\mathrm{n}$ o 9 [on line] [Available from http://migration.unu.edu/publications/policy-briefs/european-policy-debate-the-mobility-partnerships.html]. 
Serón G., Jolivel, A., Serrano Martín de Vidales, M. y Gázquez, J. L. (2011). Coherencias de políticas españolas hacia África: Migraciones. Estudios de Caso: Senegal, Malí y Mauritania. Madrid: Grupo de Estudios Africanos. [Available from http://www.uam.es/gea].
Trinidad García, M. L. (2005). Inmigrantes y mercado de trabajo: la apuesta por la contratación en origen. En Martín, J. y Trinidad García, M: L. Una forma nueva de ordenar la inmigración en España. Estudio de la Ley Orgánica 14/2003 y su reglamento de desarrollo. Valladolid: Lex Nova, pp. 150- 173. 